\title{
Diversity of Weed Species in Farms Kisii Central Sub-County, Western Kenya
}

\author{
Nyamwamu N. Charles ${ }^{1, a^{*}}$, Karanja Rebecca ${ }^{2, b}$, Mwangi Peter ${ }^{3, c}$ \\ 1,2,3 Department of Botany Jomo Kenyatta University of Agriculture and Technology, P. O. Box \\ 62000 Nairobi, Kenya
}

anyamwamucharles@gmail.com, brebeccakaranja3@gmail.com, cpnmwangi@fsc.jkuat.ac.ke

Tel. +254725566033 , Tel. +254722601849 , Tel. +254723412269

\section{Keywords: Asteraceae, Abundance, Competition, Importance Value, Smallholder Farmers}

\begin{abstract}
This study sought to determine species diversity and Importance Values (IV) of weeds in farms in Kisii Central Sub County, Western Kenya. Eight administrative sub-locations were randomly selected. Ten farms were selected at equal distance along transect laid across each sub-location. Quadrant and a line transect laid across each farm were used to collect weed species. Five rectangular quadrants of $0.5 \times 2 \mathrm{~m}$ were established in each farm and individuals of each weed species identified and counted. Importance value (IV) for each weed species was computed from density, frequency and abundance. Diversity was computed by Shannon index $\left(H^{\prime}\right)$. Twenty four weed species from 22 genera in 10 families were recorded, Family Asteraceae had the highest number of species (6), followed by Solanaceae and Poaceae with 4 and 3 species respectively. The dominant weed species were Galinsoga parviflora (IV=241.6\%), Pennisetum clandestinum (IV=215.8.7\%), Bidens pilosa (IV=196.7\%), Cynodon dactylon (IV=192.4\%), Digitaria scalarum (IV=180.8\%) and Cyperus esculentus $(172.0 \%)$. Weed species diversity was higher $\left(H^{\prime}=2.81\right)$.
\end{abstract}

\section{Introduction}

Agricultural weeds are plants that compete with crops for moisture, light, space and nutrients [14], [21]. Weeds which emerge during the first three months after planting are known to endanger yields more than those appearing later [10]. Weeds infestation also encourage disease problems, serve as alternate host for pests, slow down harvesting operation, increase the cost of production and reduce the market value of crops [1],[21].

[23] studied the weed distribution in maize fields of five Districts of the Punjab, Pakistan and they found out that weeds were the major challenge farmers were facing in their fields. They recorded that areas where proper weed knowledge on abundance and distribution was available to farmers' yields were better. Understanding abundance and distribution of weed species in the farms is an important since it helps to determine how weed species changes in response to selection pressures applied by farmers' agro-economic practices [20]. Kisii Central Sub County is one of the regions that food crops are produced for both subsistence and commercial purposes [12]. The region is blessed with fertile soils and sufficient rains that favour both crops and weeds to thrive.

\section{Materials and Methods}

\subsection{Description of the study area}

Kisii Central Sub County is one of the nine Sub Counties of Kisii County in Southwest Kenya. Temperatures can range from $10^{\circ} \mathrm{C}$ to $30^{\circ} \mathrm{C}$. According to [13], Kisii Central Sub County (formerly Kisii Central district) had a population of 588,000, but with a population growth rate of $3.6 \%$ the population is now over 700,000 (19\% of whom live in urban areas. It is one of the most densely populated Sub Counties in Kenya and covers an area of $317.4 \mathrm{Km}^{2}$. Due to the high population density, almost all land is put to maximum agricultural use. Land is subdivided within families, meaning that farm size is reducing and an average farm is only $15,000 \mathrm{~m}^{2}$ in area [18], with an average of a quarter 
of an acre allocated for arable farming throughout the Sub County and almost all farmers engage largely in subsistence and minimal commercial production. The acreage under cash crops in Kisii Central Sub County is approximately 3,800ha while the area under food crops is about 12,500ha [19]. Livestock production is dominated by dairy and local poultry. Agriculture employs an estimated 80\% of the population either directly or indirectly and the estimated rural poverty is $30 \%$ with some areas having as high as $61 \%$ according to Kisii county profile [19].

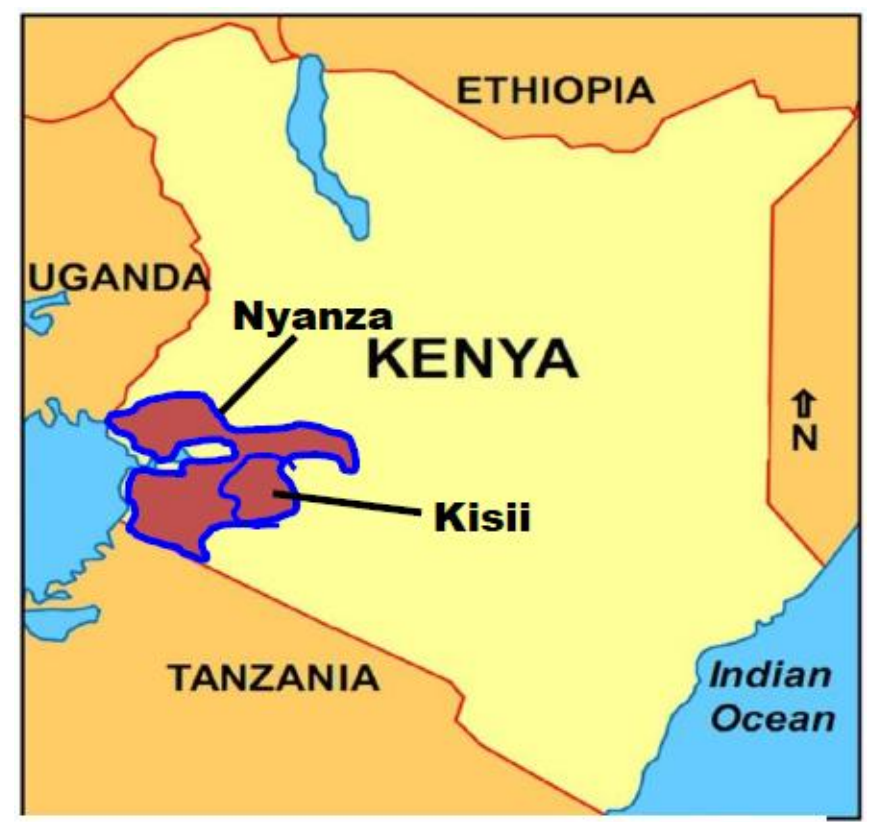

Figure 1: Kisii County, Nyanza Province of Kenya, where the research was undertaken.

Source: Adopted from Google maps (20/4/2017)



Figure 2: Kisii Sub-County Regions in Kisii County where the research was

Source: Kisii county profile plan $(20 / 4 / 2017)$

\subsection{Data collection}

Eight administrative sub-locations were randomly selected in the sub-county and then grouped into respective altitude zones based on their altitude levels from the lowest to the highest (T1 to T8). Ten farms were then selected at an equal 50m distance along a 150m transect laid across each sub-location in the study area and a survey of the weed species was done. Five quadrants of $0.5 \times 2 \mathrm{~m}$ were established in each farm along the laid line transect and collection of the weed species done. The individuals of each weed species were counted and recorded. Botanical identification of weed species was done by analysis of vegetative and reproductive parts in reference to guide books and comparing the weeds with voucher specimen deposited at National Museums of Kenya. Plant taxonomists were consulted to help identify weed species that could not be identified in the field.

\section{Data Analysis}

Assessment of phytosociological structure was done using absolute and relative values of density, frequency, abundance and importance value for each weed species [7]. The following parameters were computed;

Absolute frequency $=$ number of sampling units with species present/total number of sampling units.

Relative frequency $=$ species absolute frequency/sum of all absolute frequencies $x 100$.

Absolute density $=($ frequency/100) $\mathrm{x}$ Abundance/ no. of quadrants.

Relative density $=$ absolute density of a species/ sum of all absolute densities x 100 . 
Absolute abundance $=$ total number of individuals of a species/total number of sampling units containing that species $\mathrm{x} 100$.

Importance value $=$ relative frequency + relative density + relative abundance

Weed species diversity was evaluated using Shannon Index $\left(H^{\prime}\right)$ based on natural logarithm which considers equal weight between abundant and rare weed species. Higher values of the diversity index obtained will imply greater weed species diversity [26].

\subsection{Results}

\subsubsection{Weed species in the farms}

A total of 24 weed species belonging to 12 families were recorded in the farms and the highest numbers of weed species were recorded by family Asteraceae which dominated greatly with 6 species followed by family Solanaceae with 5 species and family Poaceae had 3 species while the rest had 2 and 1 species respectively. Most of these weed species occurred in all altitude zones, an indication of being well adapted to varied ecological conditions and can also withstand weed management practices like hoeing and hand pulling while other weed species occurred in specific localities of a few altitude zones. There were weed species families represented by 1 species as shown in Table 1.

\subsubsection{Abundance of Weed species}

Weed species were classified into families, genera and species names as shown in Table 1.

Table 1: Families, Genera and Species Names.

\begin{tabular}{|c|c|c|c|c|c|}
\hline No. & Family & Genus name & Species name & $\begin{array}{l}\text { No. of } \\
\text { individual } \\
\text { species }\end{array}$ & Total \\
\hline \multirow[t]{3}{*}{1} & \multirow{3}{*}{ Poaceae } & Pennisetum & P. clandestinum & 3987 & \multirow{3}{*}{12,215} \\
\hline & & Digitaria & D. scalarum & 3710 & \\
\hline & & Cynodon & C. dactylon & 4518 & \\
\hline \multirow[t]{6}{*}{2} & \multirow[t]{6}{*}{ Asteraceae } & Bidens & B. pilosa & 3621 & \multirow{6}{*}{16,587} \\
\hline & & Tagetes & T. minuta & 3411 & \\
\hline & & Galinsoga & G. parviflora & 5625 & \\
\hline & & Conyza & C. bonariensis & 2226 & \\
\hline & & Emilia & E. brachycephala & 1259 & \\
\hline & & Crassocephalum & C. vitellinum & 445 & \\
\hline 3 & Commelinaceae & Commelina & C. benghalensis & 1212 & 1212 \\
\hline \multirow[t]{3}{*}{4} & \multirow[t]{3}{*}{ Solanaceae } & Nicandra & N. physalodes & 877 & \multirow[b]{3}{*}{3704} \\
\hline & & \multirow[t]{2}{*}{ Solanum } & S. nigrum & 445 & \\
\hline & & & S. incanum & 1392 & \\
\hline & & Datura & D. stramonium & 864 & \\
\hline & & Physalis & P. ixocarpa & 126 & \\
\hline \multirow[t]{2}{*}{5} & \multirow{2}{*}{ Amaranthaceae } & Amaranthus & A. hybridus & 3116 & \multirow{2}{*}{3721} \\
\hline & & Achyranthes & A. aspera & 605 & \\
\hline 6 & Capparaceae & Gynandropsis & G. gynandra & 319 & 319 \\
\hline 7 & Oxalidaceae & Oxalis & O. latifolia & 1525 & 1525 \\
\hline \multirow[t]{2}{*}{8} & \multirow[t]{2}{*}{ Cyperaceae } & \multirow[t]{2}{*}{ Cyperus } & C. esculentus & 3774 & \multirow[t]{2}{*}{4858} \\
\hline & & & C. rotundus & 1084 & \\
\hline 9 & Dennstaedtiaceae & Pteridium & P. aquilinum & 224 & 224 \\
\hline \multirow[t]{2}{*}{10} & \multirow[t]{2}{*}{ Lamiaceae } & Leonotis & L. mollissima & 47 & \multirow[t]{2}{*}{89} \\
\hline & & Leucas & L. martinicensis & 42 & \\
\hline
\end{tabular}






Figure 3: Number of weed species in each family in the farms.

\subsection{Diversity of weed species in the farms}

Diversity of the weed species was calculated using Shannon index $\left(H^{\prime}\right)$;

$\boldsymbol{H}^{\prime}=-\sum \mathrm{p}_{i}\left(\ln \mathrm{p}_{i}\right)$

Where, $\boldsymbol{H}^{\prime}=$ diversity

$\sum=$ Summation,

$\mathrm{p}_{i}=\mathrm{N}_{i} \mathrm{~N}_{\text {total }}$,

ln = natural logarithim,

$\mathrm{N}_{i}=$ number of individuals of species $i$

$\mathrm{N}_{\text {total }}=$ Total number of individuals in all species

Table 2: Diversity of weed species in the farms

\begin{tabular}{|l|l|l|l|l|}
\hline Weed species & $\begin{array}{l}\text { Total No. of } \\
\text { individuals }\end{array}$ & $\begin{array}{l}\mathbf{p i}= \\
\text { Sample/sum }\end{array}$ & $\mathbf{l n}(\mathbf{p i})$ & $\mathbf{P} \boldsymbol{*} \mathbf{i n}(\mathbf{p i})$ \\
\hline Pennisetum clandestinum & 3987 & 0.089 & -2.419 & -0.215 \\
\hline Bidens pilosa & 3621 & 0.082 & -2.50 & -0.202 \\
\hline Digitaria scalarum & 3710 & 0.084 & -2.477 & -0.205 \\
\hline Commelina benghalensis & 1212 & 0.027 & -3.612 & -0.098 \\
\hline Tagetes minuta & 3411 & 0.077 & -2.564 & -0.197 \\
\hline Galinsoga parviflora & 5625 & 0.127 & -2.064 & -0.262 \\
\hline Nicandra physalodes & 877 & 0.019 & -3.963 & -0.075 \\
\hline Amaranthus hybridus & 3116 & 0.070 & -2.659 & -0.186 \\
\hline Cynodon dactylon & 4518 & 0.102 & -2.283 & -0.233 \\
\hline Solanum incanum & 1392 & 0.031 & -3.474 & -0.108 \\
\hline Gynandropsis gynandra & 319 & 0.007 & -4.962 & -0.035 \\
\hline Oxalis latifolia & 1525 & 0.034 & -3.381 & -0.115 \\
\hline Conyza bonariensis & 2226 & 0.050 & -2.996 & -0.150 \\
\hline Datura stramonium & 864 & 0.019 & -3.963 & -0.075 \\
\hline Solanum nigrum & 445 & 0.010 & -4.605 & -0.046 \\
\hline Cyperus esculentus & 3774 & 0.085 & -2.465 & -0.210 \\
\hline Emilia brachycephala & 1259 & 0.028 & -3.576 & -0.100 \\
\hline Pteridium aquilinum & 224 & 0.005 & -5.298 & -0.027 \\
\hline
\end{tabular}




\begin{tabular}{|l|l|l|l|l|}
\hline Crassocephalum vitellinum & 445 & 0.010 & -4.605 & -0.046 \\
\hline Leonotis mollissima & 47 & 0.001 & -6.908 & -0.0069 \\
\hline Leucas martinicensis & 42 & 0.0009 & -7.013 & -0.0063 \\
\hline Physalis ixocarpa & 126 & 0.003 & -5.801 & -0.017 \\
\hline Cyperus rotundus & 1084 & 0.024 & -3.730 & -0.092 \\
\hline Achyranthes aspera & 605 & 0.014 & -4.269 & -0.100 \\
\hline \multicolumn{2}{|r|}{ SUM $=\mathbf{4 4 , 4 5 4}$} & \multicolumn{2}{|c|}{ TOTAL $=\mathbf{- 2 . 8 0 7}$} \\
\hline
\end{tabular}

$H^{\prime}=\mathbf{2 . 8 1}$

Diversity index $\boldsymbol{H}^{\prime}=$ summing up of pi $* \ln (\mathrm{p} i)$ of each weed species.

\subsubsection{Weed species Importance Value}

Importance value of each weed species was calculated and tabulated as shown in Table 3.

Table 3: Weed species importance value in farms across the altitude zones.

\begin{tabular}{|l|l|l|l|l|l|l|l|l|l|}
\hline Botanical name & T1 & T2 & T3 & T4 & T5 & T6 & T7 & T8 & TOTAL \\
\hline Galinsoga parviflora & 30.9 & 30.3 & 33.9 & 32.4 & 34.9 & 20.3 & 30.6 & 28.3 & $\mathbf{2 4 1 . 6}$ \\
\hline Pennisetum clandestinum & 25.8 & 23.1 & 30.1 & 32.5 & 33.5 & 21.7 & 29.1 & 20.0 & $\mathbf{2 1 5 . 8}$ \\
\hline Bidens pilosa & 28.4 & 22.2 & 29.2 & 23.3 & 28.8 & 20.3 & 22.9 & 21.6 & $\mathbf{1 9 6 . 7}$ \\
\hline Cynodon dactylon & 28.4 & 24.0 & 18.3 & 22.9 & 28.3 & 19.6 & 24.1 & 26.8 & $\mathbf{1 9 2 . 4}$ \\
\hline Digitaria scalarum & 24.8 & 23.8 & 26.6 & 19.2 & 21.9 & 18.4 & 24.6 & 21.5 & $\mathbf{1 8 0 . 8}$ \\
\hline Cyperus esculentus & 25.1 & - & 25.6 & 21.1 & 29.8 & 22.2 & 23.7 & 24.5 & $\mathbf{1 7 2 . 0}$ \\
\hline Tagetes minuta & 18.9 & 19.1 & - & 23.9 & 19.4 & 17.8 & 26.8 & 24.5 & $\mathbf{1 5 0 . 4}$ \\
\hline Amaranthus hybridus & 24.1 & 26.1 & 16.2 & 26.8 & 28.2 & 18.4 & - & - & $\mathbf{1 3 9 . 8}$ \\
\hline Conyza bonariensis & 15.5 & 18.1 & 13.7 & 16.5 & 19.5 & 11.8 & 20.5 & 17.5 & $\mathbf{1 3 3 . 1}$ \\
\hline Emilia brachycephala & - & 12.8 & 11.0 & 14.6 & 13.5 & 8.6 & 15.2 & 12.1 & $\mathbf{8 7 . 8}$ \\
\hline Solanum incanum & 11.2 & 14.9 & 12.4 & - & - & 15.2 & 13.3 & 15.5 & $\mathbf{8 2 . 5}$ \\
\hline Commelina benghalensis & 10.4 & 15.5 & 15.2 & 10.4 & - & 9.1 & 12.8 & 9.0 & $\mathbf{8 2 . 4}$ \\
\hline Oxalis latifolia & 10.7 & 12.9 & - & - & - & 13.0 & 17.9 & 15.9 & $\mathbf{7 0 . 4}$ \\
\hline Datura stramonium & - & 14.9 & 9.4 & - & 12.8 & 7.4 & 12.4 & 9.3 & $\mathbf{6 6 . 2}$ \\
\hline Nicandra physalodes & 14.7 & 10.7 & 15.2 & 16.1 & - & 8.7 & - & - & $\mathbf{6 5 . 4}$ \\
\hline Cyperus rotundus & & 11.5 & 10.1 & - & - & 13.3 & 14.3 & 14.9 & $\mathbf{6 4 . 1}$ \\
\hline Solanum nigrum & 11.1 & 11.2 & - & 16.5 & - & 9.0 & - & - & $\mathbf{4 7 . 8}$ \\
\hline Crassocephalum vitellinum & - & 9.7 & 7.3 & 7.9 & - & 5.8 & 12.0 & 4.8 & $\mathbf{4 7 . 5}$ \\
\hline Achyranthes aspera & - & - & 7.6 & - & 18.5 & - & - & 13.0 & $\mathbf{3 9 . 1}$ \\
\hline Physalis ixocarpa & - & - & - & 21.2 & 10.7 & - & - & - & $\mathbf{3 1 . 9}$ \\
\hline Leucas martinicensis & - & - & 18.7 & - & - & - & - & 2.6 & $\mathbf{2 1 . 3}$ \\
\hline Pteridium aquilinum & - & - & 12.3 & - & - & - & - & 4.7 & $\mathbf{1 7 . 0}$ \\
\hline Gynandropsis gynandra & 4.8 & - & - & - & - & - & - & 10 & $\mathbf{1 4 . 8}$ \\
\hline Leonotis mollissima & 6.3 & - & - & - & - & - & - & 3.4 & $\mathbf{1 0 . 0}$ \\
\hline
\end{tabular}

\subsection{Discussion}

\subsection{Abundance of Weed species Families.}

A total of 24 weed species belonging to 12 families were recorded in the farms and the highest numbers of weed species were recorded by family Asteraceae which dominated greatly with 6 species followed by family Solanaceae with 5 species and family Poaceae had 3 species while the rest had 2 and 1 species respectively as shown in Figure 3. Most of these weed species occurred in all altitude zones, an indication of being well adapted to varied ecological conditions and can also withstand weed management practices like hoeing and hand pulling while other weed species occurred in specific localities of a few altitude zones. There were weed species families represented by 1 species as shown in Table 3. Similar studies were conducted by [30] and found out the weed communities of 
wheat crop in district Toba Tek Singh, Pakistan and reported 38 weed species \distributed among 35 genera and 17 families were recorded while [17] studied the importance Value Index (I.V.I) of weed flora of some maize fields of Tehsil Gojra and reported 34 weeds which were distributed among 17 different plant families. In another study, [2] reported twenty three species of 13 families of weeds of wheat yield from five different localities of village Qambar, District Swat in Pakistan. In a similar study conducted by [16] in Coffee estates in Kiambu County, Kenya, they reported 19 families comprising of 47 weed species. [11], also noted that agricultural intensification affects weed species in arable farms. These results demonstrated that weed species number in arable farms significantly decreased with extreme altitude levels, similarly to the findings from Central Europe [15] However, [22] confirmed that species number is negatively correlated with elevation. According to [27], the number of non-native plant species decreased strongly with elevation extremes. Weed species $P$. clandestinum, G. parviflora, $B$ pilosa, $\quad$ D. $\quad$ scalarum, $C$. dactylon and $C$. bonariensis occur in all altitude zones regardless of prevailing ecological conditions, an indication of having well adaptive characteristics to various habitats while others like L. mollissima, L. martinicensis, G. gynandra and P. aquilinum were found to occur in only extreme altitude levels hence an indication of having limited adaptive features to varied habitats. Weed management practices in the studied arable farms can be an important factor in determining species abundance in this study. Low input fields had significantly more species than intensively managed ones.

\subsection{Weed species Diversity}

Typical values are generally between 1.5 and 3.5 in most ecological studies, and the index is rarely greater than 4.0 [26]. The Shannon index increases as abundance of a community increases. The higher values of $H^{\prime}$ indicate greater floristic diversity [26].

The diversity index $\left(H^{\prime}\right)$ obtained was 2.81 as shown in Table 2 and this result agrees with those of similar studies done in other tropical areas such as that conducted by [3] who obtained diversity index of 2.53 of weed species in rice fields in Brazil. In the farms, most weed species demonstrated great capacity to adapt and occur in different altitude zones and tolerance to human management practices.

\subsection{Weed species Importance Value}

Importance value is the most comprehensive indicator of phytosociology of a given habitat. Table 3 reveals that G. parviflora, P. clandestinum, B. pilosa, C. dactylon, D. scalarum and C. bonariensis had relatively high I.V and occurred in all altitude zones (T). C. esculentus also scored relatively high though it did not occur in altitude T2. A. hybridus also recorded a relatively high I.V though it did not occur in altitude zones T7 and T8. Structural variability in the floristic composition varied across the altitude zones. G. parviflora ranked as the top scorer at zone T5 and T3 having the Importance Value of 34.9 and 33.9 respectively. Similarly, P. clandestinum had the highest Importance value (33.5) at zone T5, while B. pilosa had the highest I.V of 29.2 at zone T3. Weed species E. brachycephala occurred in all altitude zones except zone (T1) and attained I.V of 87.8. D. stramonium scored I.V. of 82.5 and was not found in zone T4 and T5. G. gynandra and L. mollissima occurred only in two zones, T1 and T8 and scoring an aggregate I.V of 14.8 and 10.0 respectively while $P$. ixocarpa also occurred in two zones T4 and T5 and attained an aggregate I.V of 31.9. Similarly, L. martinicensis occurred in two altitude zones, T3 and T8 and scored an aggregate I.V of 21.3. A. aspera, though it occurred only in zone T3, T5 and T8 managed to attain I.V of 39.1. Weed species with relatively higher I.V had a reasonable stand in all the altitude zones depicting their widespread occurrence in study area. The Total Importance value summarizes the predominance of weed species in mathematical terms. In order to obtain potential crop yields from the study area effective management of these weed species is therefore required. As revealed earlier the proportionate composition varies from zone to zone, evidently the abundant species like $P$. clandestinum, $D$. scalarum and $C$. esculentus needs to be addressed because they not only competes with the crop for nutrients, light and space, but also it increases the cost of production in controlling them. The seven most dominant weed species were Galinsoga parviflora (IV=241.6\%), Pennisetum 
clandestinum (IV=215.8\%), Bidens pilosa (IV=196.7\%), Cynodon dactylon (IV=192.4\%), Digitaria scalarum (IV=180.8\%), Cyperus esculentus (IV=172\%) and Tagetes minuta (IV=150.4\%). G. parviflora is an American weed, and its centre of origin is considered to be the mountainous area of Mesoamerica [28]. It is a fast-growing annual herb with the capacity to invade agricultural and other disturbed areas in most temperate and subtropical regions of the world [9]. It is also highly competitive and can spread quickly, often being the dominant species in a field and generates significant economic impact on crop systems, greenhouses, gardens and nurseries [6].

Pennisetum clandestinum is a rhizomatous grass with matted roots and a grass-like or herbaceous habit, it is resistant to grazing or mowing since it has extensive root network and easily forms new shoots [5]. It can climb over other plant life, shading it out and produce herbicidal toxins that kill competing plants [6]. Bidens pilosa commonly known as cobbler's peg is widely distributed in tropical and subtropical regions of the world and is reported to be a weed of 31 crops. [7], [25] provided a checklist of noxious weeds in various crops of District Mansehra, Khyber Pakhtunkhwa Pakistan.

[8] conducted a study and found out reciprocal competition effects between Cynodon dactylon and most arable crops like maize. D. scalarum is a creeping, perennial grass with long, slender, branching rhizomes which form a dense mat beneath the soil surface. It occurs as a weed in a wide range of crops and soils, including those where minimum tillage is practised. It is a common component of natural grasslands at higher altitudes in East Africa [4]. Cyperus esculentus is a grass-like weed in the sedge family (Cyperaceae) and it is a major weed of vegetable and row crops in temperate and tropical regions around the world with extensive underground network of basal bulbs, roots and rhizomes. It is aggressive in irrigated crops that are maintained at high soil moisture [31] and is considered a major weed of vegetables, corn, cotton, and peanuts in the southern United States [29]. Tagetes minuta has been reported that it is a weed of 19 crops in 35 countries infesting $10 \%$ of maize fields, and may be particularly severe in low-growing crops such as beans [9]. Its presence in crops leads to skin irritation to agricultural workers, contaminates milk when there is external contact between the plant and cattle udders (imparts an objectionable flavour).

\section{Conclusion}

This study was conducted for determination of diversity, abundance and Importance Value of weed species in arable farms in Kisii central sub-county. During the study, a total of 24 weed species of 10 different families were reported. These results pointed out seven dominant and major weed species in the arable farms that have been problematic to crops. The seven dominant weeds were Pennisetum clandestinum, Bidens pilosa, Digitaria scalarum, Galinsoga parviflora, Cynodon dactylon, Tagetes minuta and Cyperus esculentus.

Having evaluated weed species diversity in the study area, it is quite easier to formulate long term weed management guidelines. The dominant weed species, their families and importance values that contributed to the weed flora were also put into account. In addition, occasional introduction of new weed species can easily be monitored and noted because of having a record of the weed species diversity of the previous years. These findings could help predict infestation and thus lead to improved weed management measures in arable farms especially for smallholder farmers in Kisii central sub county.

\section{Conflict of Interest}

"The author(s) declare(s) that there is no conflict of interest."

There was no role of the funding sponsors in the design of the study; in the collection, analyses or interpretation of data; in the writing of the manuscript, or in the decision to publish the results. 


\section{Acknowledgement}

The author would like to acknowledge the input, support and guidance accorded by the project study supervisors, the botany department of Jomo Kenyatta University of Agriculture and Technology, all the farm managers and management staff of the surveyed farms, the survey biometricians, the librarians at the museums of Kenya, Mr. Wanjohi, P. K. (University of Eldoret) and botany departments (Kisii University).

\section{References}

[1]B.O. Ademiluyi, C. M. Abegunde (2007) Evaluation of hoeing and herbicide spray programs in maize in S. W. Nigeria. Res. J. Agron, 1(2) 38-41.

[2]N. Akhtar, and F. Hussain (2007). Weeds of wheat of village Qambar, District Swat, Pakistan. Pak. J. Pl. Sci. 13(1): 33-37.

[3]M. V.M. Andrade et al., (2009). Levantamento florístico e estrutura fitossociológica do estrato herbáceo e subarbustivo em áreas de caatinga no Cariri paraibano. Revista Caatinga, v. 22, n. 1, p. 229-237.

[4]S. D. Baguma, M. Webb and D.S.O. Osiru (1995). Control of Digitaria abyssinica (A. Rich.) Stapf. with glyphosate. Africa Crop Science Journal, 3:433-442.

[5]W.D. Clayton, K. T. Harman and H. Williamson (2008). "Pennisetum clandestinum". GrassBase. The Online World Grass Flora. Royal Botanic Gardens, Kew. Retrieved 2008-11-09.

[6]C. A. Damalas (2008). Distribution, biology, and agricultural importance of Galinsoga parviflora (Asteraceae). Weed Biology and Management, 8(3):147-153.

[7]M. D. Dombois and H. Ellenberg (1974) Aims and methods in vegetation ecology. John Wiley and Sons, New York. Reprint (2003) Blackburn Press, ISBN 1-930665-73-3.

[8]O.N. Fernandeza, O. R. Vignolioa and E. C. Requesens (2002). Competition between corn (Zea mays) and bermudagrass (Cynodon dactylon) in relation to the crop plant arrangement. Agronomie. 22: 293-305.

[9]L. G. Holm et al., (1997). Weeds: Natural History and Distribution: John Wisley and sons. New York, USA.

[10] A. G. Iyagba (2010) A review on root and tuber crop production among small scale farmers. In Nigeria. ARPN Journal of Agriculture and Biological Science. Vol.5 No 1.

[11]L. José-María et al., (2010). Effects of agricultural intensification on plant diversity in Mediterranean dryland cereal fields. J. Appl. Ecol. 47: 832-840.

[12]KALRO, (2013) Kenya Agricultural Livestock and Research Organization. Food crop Production for both Subsistence and Commercial purposes.

[13] KNBS (Kenya National Bureau of Statistics), (2009) Kenya population and Housing Census.

[14] S. Mahmoodi and A. Rahimi (2009) Estimation of critical period of weed control in corn in Iran, Weed acad. Sc., 49:67-72.

[15]Z. Lososová et al., ( 2004). Weed vegetation of arable land in Central Europe: Gradients of diversity and species composition. J. Veg. Sci. 15: 415-422.

[16]R. W. Michieka, G. G. Migwi and E. S. Ariga (2017) A survey on weed diversity in coffee estates with prolonged use of glyphosate in Kiambu county, Department of plant science and crop protection, faculty of agriculture, College of agriculture and veterinary sciences, University of Nairobi, Kenya. International Journal of Scientific Research and Innovative Technology ISSN: 2313-3759 Vol. 4 No. 2. 
[17] S. Muhammad, Z. Khan and T. A. Cheema (2009): Distribution of weeds in wheat, maize and potato fields of tehsil Gojra, district Toba Tek Singh, Pakistan. Pakistan Journal of Weed Science Research: 15, 91-105.

[18] MoA (Ministry of Agriculture), (2009) Farm Management Handbook of Kenya Vol. II Natural Conditions and Farm Management Information. 2nd Edition, Part a West Kenya Subpart A2 Nyanza Province MoA Kenya in Cooperation with GTZ. Ministry of Agriculture, Nairobi.

[19] MoA (Ministry of Agriculture), (2012) Annual Work Plan: Kisii County. Ministry of Agriculture, Nairobi.

[20]R. Nkoa, M.D.K. Owen and C. J. Swanton (2015) Weed Abundance, Distribution, Diversity and Community Analyses. Weed Science, 63: 64-90.

[21]P. Oudhia (2004) Phyto-sociological studies of rainy wasteland, pp. 40.In Liebman, C.L., Parker, V.T., and Fryer, S.L. (2004) Ecology of Soil Seed bank, Academic Press New York. pp.3-8.

[22]P. Pyšek (1993). Factors affecting the diversity of flora and vegetation in central European settlements. Vegeiatio 106: 89-100.

[23]N. Rabbi and Bajwa, (2010) Weed distribution in rice fields in Punjab. Pak. J. Bot. 33(special issue).

[24] J. A. Ratter, S. Bridgewater and J. F. Ribeiro (2003) Analysis of the floristic composition of woody vegetation III: Comparison of woody vegetation of 376 areas. Edinburgh Journal of Botany, vol. 60, no. 1, p. 57-109.

[25]G. M. Shah and M. A. Khan ( 2006). Checklist of noxious weeds of district Mansehra, Pakistan. Pak. J. Weed Sci. Res., 12(3): 213-219.

[26]C. E. Shannon and W. Weiner (1949) The mathematical theory of communication. Urbana University of Illinois Press

[27]C. Siniscalco, E. Barni and G. Bacaro (2011). Non-native species distribution along the elevation gradient in the western Italian Alps. Plant Biosyst 145: 150-158.

[28]H. Vibrans (2009). Malezas de México. Listado alfabético de las especies, ordenadas por género (Weeds of Mexico. Alphabetical list of species, ordered by genera).

[29] T. M. Webster (2006). Weed survey-southern states. Vegetable, fruit and nut crops subsection. Proceedings of the Southern Weed Science Society 59: 260-277.

[30]R. A. Qureshi, A. Waheed and M. Arshad (2009) Weed Communities of wheat crop in District Toba Tek Singh. Pak. J. Bot., 41(1): 239-415.

[31]C. V. Ransom, C. A. Rice and C. C. Shock (2009). Yellow nutsedge (Cyperus esculentus) growth and reproduction in response to nitrogen and irrigation. Weed Science 57: 21-25. 